\title{
Pemberdayaan Suku Anak Dalam (SAD) Melalui Peningkatan Kualitas Pendidikan Informal Dalam Pencegahan Pandemi Covid-19 Di Desa Nyogan Kecamatan Mestong Kabupaten Muaro Jambi
}

\author{
Upik Yelianti $^{1}$, Amelia Dwi Fitri ${ }^{2}$, Mulawarman ${ }^{3}$, Zulfanetty ${ }^{4}$ \\ 1) Pusat Studi Pendidikan Masyarakat LPPM Universitas Jambi \\ 2) Pusat Studi Kesehatan Reproduksi LPPM Universitas Jambi \\ ${ }^{3)}$ Pusat Studi Mitigasi dan Bencana Alam LPPM Universitas Jambi \\ 4) Pusat Studi Perencanaan Pembangunan dan Keuangan Daerah LPPM Universitas Jambi \\ Coresponding author Email: upikyelianti@ymail.com
}

\begin{abstract}
ABSTRAK
Dusun Sugandi Desa Nyogan merupakan suatu kawasan transosial yang didominasi oleh Suku Anak Dalam (SAD) dengan luasan sekitar $7.872 \mathrm{~km}^{2}$ dengan jumlah pendudukan sekitar 3.390 jiwa. Di dusun Sugandi ini terdapat satu sekolah dasar yaitu SDN 238/IX dengan siswa yang umumnya berasal dari Suku Anak Dalam (SAD), dengan jumlah siswa sekitar 96 orang siswa, 6 orang guru honorer dan 1 kepala sekolah (PNS). Akses jalan ke sekolah ini tidak baik, jika hari hujan lebat maka jalan dan halaman sekolah menjadi tergenang. Di masa pandemic covid19, sekolah hanya buka setiap hari Sabtu, dan siswa hanya belajar dari rumah dan didampingi oleh orang tuanya. Rendahnya motivasi belajar siswa dan kurang nya pengetahuan orang tua merupakan kendala yang sangat penting untuk dicarikan solusinya. Tim PPM Universitas Jambi telah melakukan kegiatan pendampingan dengan metode PRA (Participatory Rural Apraisal) dengan melibatkan guru, siswa dan orang tua murid dalam memecahkan masalah yang dihadapi. Tahapan kegiatan yang sudah dilakukan adalah: 1) Peningkatan motivasi siswa SDN 238/IX Sugandi dalam pembelajaran, 2) Pendampingan dalam pelaksanaan pembelajaran Aktif, 3) Sosialisasi dan demonstrasi menjaga kesehatan mulut, gigi, gerakan cuci tangan dan jaga jarak dalam pencegahan penularan virus corona dimasa pandemic, dan 4) Pengelolaan pekarangan sekolah sebagai kebun Toga yang ditanami sayuran, obat dan buah sebagai upaya untuk mencegah penularan covid-19, serta 5) Pemberian bantuan bibit, makanan sehat dan vitamin. Kegiatan ini disambut baik oleh khalayak sasaran terlihat dari antusiasme guru, siswa, dan orang tua dalam mengikuti kegiatan ini. Diharapkan kegiatan PPM ini dilanjutkan dengan materi yang lebih komprehensif agar masyarakat merasakan manfaatnya.
\end{abstract}

\section{PENDAHULUAN}

Berdasarkan hasil observasi dan monitoring kegiatan PPM yang sudah dilakukan di tahun 2019 di dusun Nyogan ini, masih banyak permasalahan yang harus dibenahi dalam pemberdayaan Suku Anak Dalam (SAD), antara lain: Perbaikan kualitas pembelajaran di SDN 238/IX dusun Nyogan, perbaikan kualitas kesehatan diri dan lingkungan serta pemanfaatan lahan pekarangan sekolah dan pekarangan rumah masyarakat di daerah trasnsosial Sugandi Dusun Nyogan. Oleh karena itu, perlu dilakukan berbagai usaha dalam pemberdayaan Suku Anak Dalam (SAD) melalui peningkatan kualitas pendidikan informal. Di samping kegiatan pendidikan formal di sekolah SDN 238/IX Sugandi, yaitu dengan memberikan pemodelan pembelajaran menyenangkan dan joyfull diharapkan siswa SD 238/IX dapat meningkat motivasinya dalam belajar dan pada akhirnya akan meningkatkan hasil belajarnya. Beberapa kegiatan pembelajaran informal dapat dilakukan dengan mendemonstrasikan cara menjaga kesehatan mulut dan gigi, serta gerakan cuci tangan di masa New Normal setelah pandemic covid 19. Pemberdayaan ibu- 
ibu rumah tangga terutama orang tua murid SDN 238/IX Sugandi juga dapat dilakukan dengan pembuatan contoh pemanfaatan lahan pekarangan sekolah melalui Pembuatan Kebun Toga dengan menanam sayuran dan buah-buahan serta tanaman untuk pemenuhan kebutuhan seharihari. Berikut ini kondisi SD N 238/IX Desa Nyogan disajikan pada Gambar 1 berikut ini:

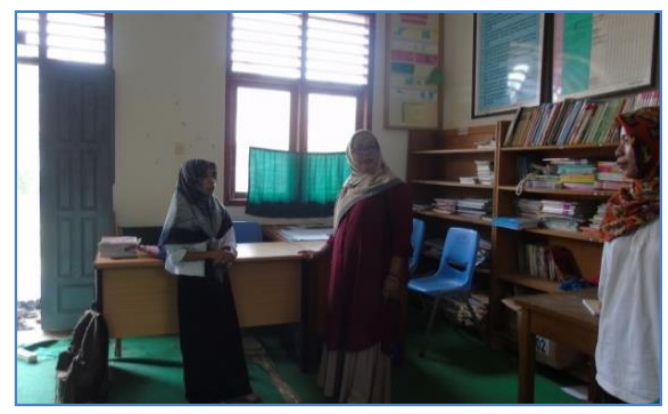

(a)

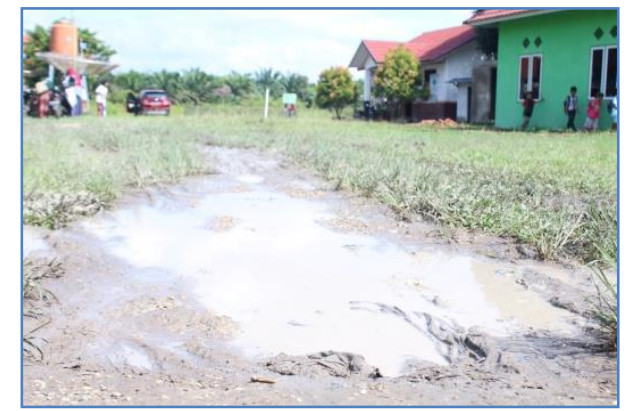

(b)

Gambar 1. Kondisi SD N 238/IX Transosial Sugandi Desa Nyogan Kecamatan Mestong (a) Lingkungan sekolah (b) Akses jalan ke sekolah

Kegiatan Pengabdian kepada Masyarakat ini melibatkan berbagai Pusat Studi di LPPM Universitas Jambi, yaitu: Pusat Studi Pendidikan Masyarakat, Pusat Studi Kesehatan Reproduksi, Pusat Studi Mitigasi dan Bencana Alam, serta Pusat Studi Perencanaan Pembangunan dan Keuangan Daerah secara bersama-sama bersinergi mengadakan kegiatan secara terpadu untuk meningkatkan pengetahuan dan keterampilan masyarakat dalam rangka memperbaiki kualitas hidup khalayak sasaran. Di samping pendidikan formal yang dilakukan di sekolah dasar Negeri 238/IX Desa Nyogan juga dilakukan pendidikan informal kepada masyarakat umum khususnya orang tua siswa SDN 238/IX Sugandi. Di samping itu juga diberikan pendidikan informal kepada masyarakat Desa Nyogan, seperti: pentingnya menjaga kesehatan mulut dan gigi serta gerakan cuci tangan untuk menjaga kesehatan di masa new normal pandemic covid 19, serta memanfaatkan lahan pekarangan sekolah dalam pemenuhan kebutuhan sehari-hari dengan menanami tanaman sayuran dan buah. Melalui kegiatan Pemberdayaan Suku Anak dalam melalui peningkatan kualitas pendidikan dapat pengetahuan dan keterampilan masyarakat Desa Nyogan dalam pencegahan dan penanggulangan bahaya penyebaran virus covid 19. Demikian juga dengan masyarakatnya akan lebih menjaga dan peduli dengan kesehatan diri sendiri dan lingkungannya, sehingga diperoleh kehidupan yang damai dan nyaman.

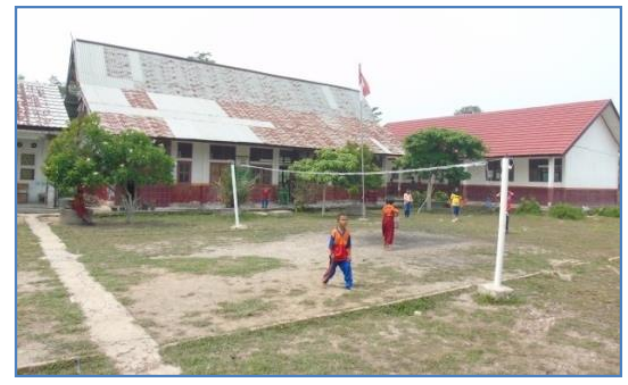

(a)

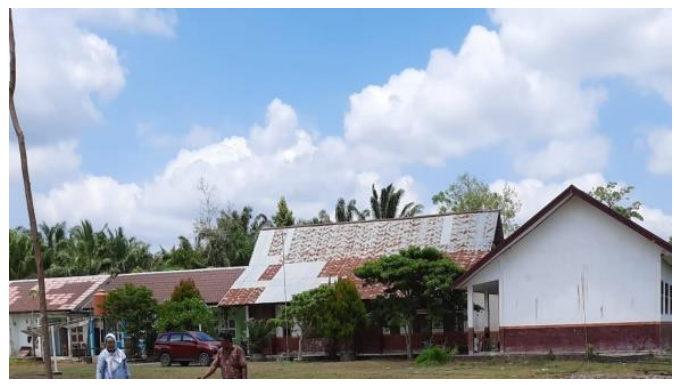

(b)

Gambar 2. Halaman sekolah SDN 238/IX Sugandi (a) dan Gedung sekolah SDN 238/IX (b) 


\section{Permasalahan Mitra}

Permasalahan utama yang dihadapi oleh masyarakat dusun Sugandi desa Nyogan yang pada umumnya terdiri dari Suku Anak Dalam (SAD) adalah kualitas pendidikan yang rendah, baik siswa maupun orang tuanya. Siswa SDN 238/IX memiliki motivasi yang rendah dalam belajar.

Di masa pandemic covid-19 ini sekolah hanya buka dihari Sabtu saja dan itupun terbatas jam pertemuannya. Siswa hanya diperkenankan belajar di rumah dengan dibantu oleh orang tuanya, dimana orang tua murid juga memiliki kemampuan yang sangat rendah. Di samping itu, masyarakat desa Sugandi kurang memahami bagaimana penyebaran dan usaha pencegahan serangan virus corona tersebut. Kondisi lahan pekarangan sekolah yang luas dan belum dimanfaatkan secra optimal dapat dijadikan sebagai pilot percontohan bagi siswa dan orang tua murid untuk dikelola sebagai kebun Toga yang bisa ditanami dengan tanaman sayuran, obat dan buah, sehingga dapat meningkatkan gizi masyarakat di masa pandemic covid-19.

\section{METODE PELAKSANAAN}

Berdasarkan permasalahan yang telah diuraikan dan tujuan yang ingin dicapai, maka jadwal kegiatan program PPM Skim Covid 19 Universitas Jambi disesuaikan dengan jadwal khalayak sasaran yaitu kepala sekolah, guru-guru dan siswa, serta orang tua murid SD N 238/IX daerah transosial dusun Nyogan untuk kegiatan pendidikan informal. Selama masa new normal SDN 238/IX hanya aktif di sekolah setiap hari Sabtu. Pada hari sabtu guru dan siswa serta kepala hadir di sekolah untuk memberikan tugas yang akan dikerjakan di rumah dan mengumpulkannya seminggu yang akan datang. Oleh karena itu kegiatan PPM dari tim PPM Unja juga melaksanakan kegiatan PPM setiap hari sabtu setelah kegiatan guru dan siswa selesai.

Metode pengabdian yang digunakan adalah PRA (Participatory Rural Apraisal), yaitu suatu metode pendidikan dengan melibatkan kepala sekolah, guru-guru dan siswa SD N 238/IX Dusun Nyogan sebagai subjek khalayak sasaran. Kelebihan dari metode PRA ini adalah melibatkan partisipasi aktif dari guru-guru, siswa dan orang tua siswa SDN 238/IX Suandi sebagai khlayak sasaran yang bertindak sebagai subyek dan pihak tim PPM Universitas Jambi sebagai fasilitator.

Kegiatan PPM ini telah dilaksanakan di SD N 238/IX Desa Nyogan dengan melibatkan kepala sekolah, guru-guru dan siswa, serta orang tua murid sekolah dasar tersebut dalam bentuk pendidikan informal. Orang tua siswa juga dilibatkan bertujuan untuk membantu para siswa agar dapat belajar di rumah dimasa pandemic covid 19 ini. Pada umumnya orang tua siswa ada yang belum bisa membaca dan menulis, sehingga sulit untuk membantu anaknya belajar di rumah. Oleh karena itu, belajar bersama antara siswa dan orang tuanya pada saat menanam sayuran dan buah serta tanaman obat adalah suatu cara yang sangat tepat dilakukan. Kegiatan PPM dengan metode PAR ini terdiri dari beberapa rangkaian kegiatan yaitu: Pemodelan pembelajaran yang menyenangkan dengan menerapkan berbagai metode yang variatif dan menyenangkan yang melibatkan guru dan siswa SDN 238/IX Dusun Nyogan, Demonstrasi dan praktek tentang mencuci tangan dan menggososk gigi yang baik dan benar, sehingga kesehatan mulut dan gigi terjaga dan melibatkan partisipasi aktif dari guru-guru dan siswa SD N 238/IX Desa Nyogan. Selanjutnya pemberdayaan masyarakat dalam mengelolan lahan pekarangan sekolah yang melibatkan guru dan siswa serta ibu-ibu orang tua murid.

Tahapan kegiatan tersebut adalah sebagai berikut:

a. Pemodelan pembelajaran yang menyenangkan dengan menerapan metode yang variatif, yang mneyebabkan siswa termotivasi dalam mengikuti pembelajaran, sehingga kualitas pendidikan di sekolah dasar khususnya di SD N 238/IX Desa Nyogan jadi meningkat. 
b. Melakukan sosialisasi dan praktek mengenai pencegahan penyebaran Covid-19 serta pemberdayaan masayarakat setelah New Normal.

c. Demonstrasi tentang cara menggosok gigi dan mencuci tangan yang baik dan benar pada siswa SDN 238/IX Dusun Nyogan.

d. Demonstrasi tentang pengelolaan lahan pekarangan yang masih kosong dengan jalan menanam tanaman sayuran dan buah serta tanaman obat, sehingga dapat memenuhi kebutuhan gizi dan obat keluraga, bahkan jika berlebih akan dapat dijual dan tentu akan menambah income keluarga.

e. Evaluasi: monitoring dan evaluasi dapat dilakukan setiap kali berkinjung ke lokasi kegiatan PPM, dan untuk melihat tingkat ketercapaian dan keterlaksanaan program PPM yang sudah dilakukan. Evaluasi dilakukan untuk melihat apakah program ini dapat memberikan manfaat langsung bagi guru-guru dan siswa SD N 238/IX Desa Nyogan terutama dalam menerapkan berbagai metode dalam pembelajaran di dalam kelas, sehingga anak didik menjadi termotivasi dalam mengikuti pmbelajaran di sekolah. Paritisipasi mitra berupa penyediaan fasilitas tempat dan ruangan di SD N 238/IX Desa Nyogan.

\section{HASIL KEGIATAN}

\section{Hasil Kegiatan PPM}

Kegiatan Pengabdian Kepada Masyarakat telah dilaksanakan di dusun Sugandi Desa Nyogan dengan khalayak sasaran adalah Guru-guru SD, siswa SDN 238/IX serta orang tua murid. Kegiatan ini telah berlangsung sebanyak 8 kali kunjungan.

Berdasarkan Tabel 1. terlihat bahwa beberapa kegiatan yang telah dilakukan oleh Tim PPM Universitas Jambi yang dimulai dari konsolidasi dan pengurusan izin sampai pada kegiatan pendampingan dalam pembelajaran aktif dan menyenangkan di sekolah SDN 238/IX bersama guru-guru, siswa dan orang tua murid. Orang tua murid juga ikut belajar dengan tujuan bahwa pada masa pendemic ini dimana siswa belajar di rumah yang dibimbing oleh orang tua, sementara orang tuanya tidak memiliki kemampuan dalam membimbing anaknya karena tingkat pendidikan orang tua yang sangat rendah. Akan tetapi, orang tua murid tidak banyak yang ikut, karena mereka harus bekerja di luar rumah. Dokumentasi kegiatan disajikan sebagai beikut:

Survey dan konsolidasi 


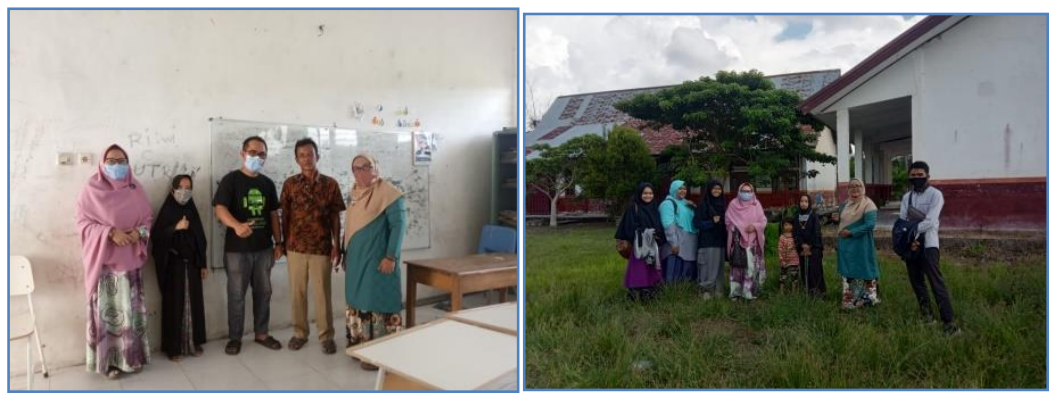

Kegiatan Pembelajaran aktif di SDN 238/IX Sugandi
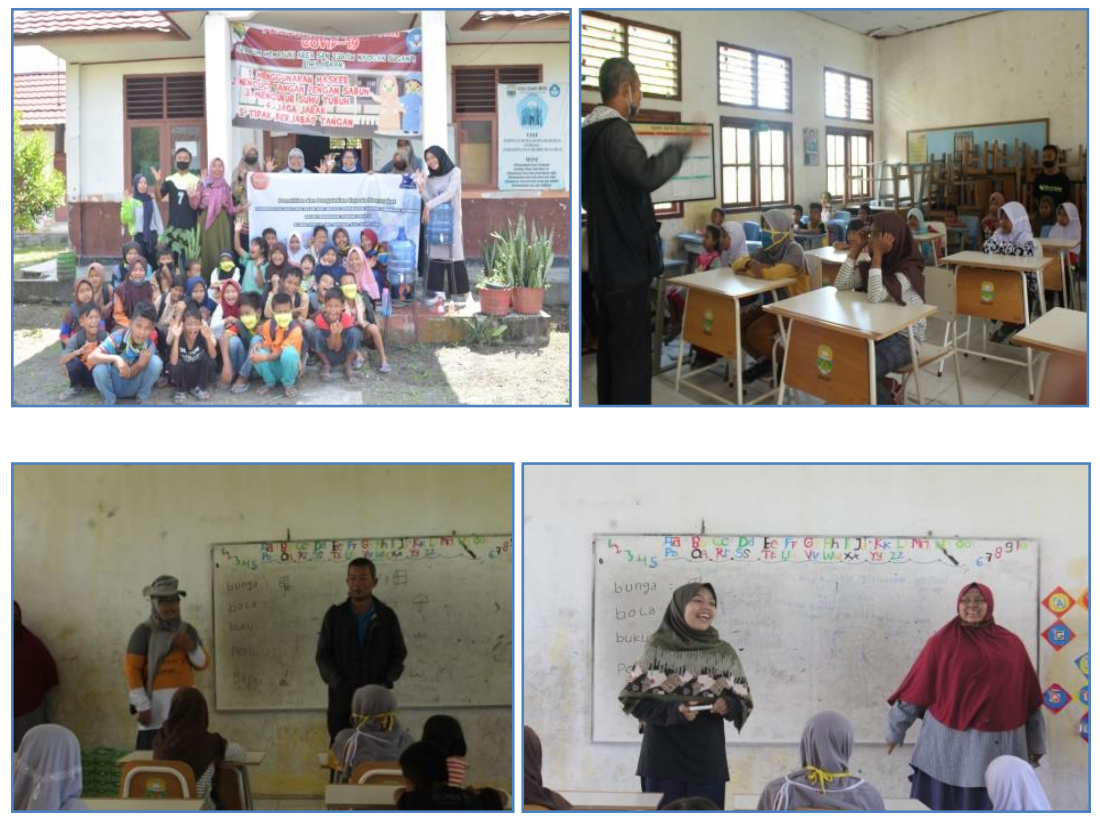

Pembelajaran aktif dan menyenangkan serta pemberian motivasi pada siswa

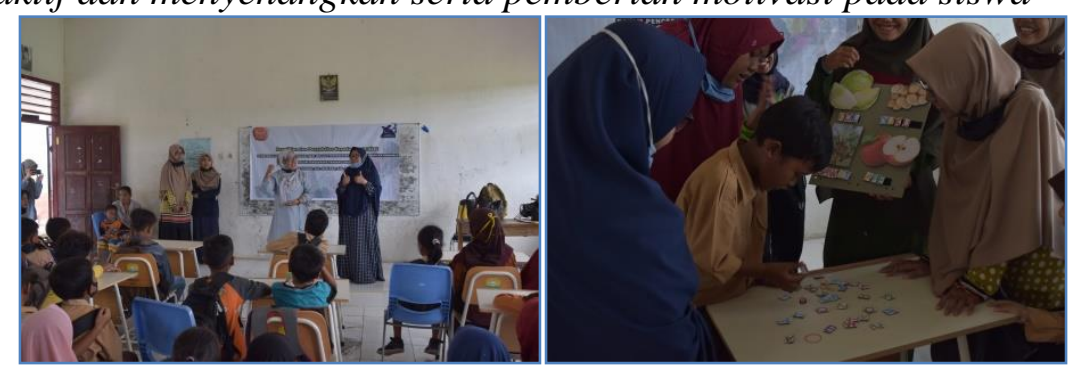

Kegiatan Sosialisasi Menjaga Kesehatan dan Praktek Pencegahan Penyebaran Covid-19 

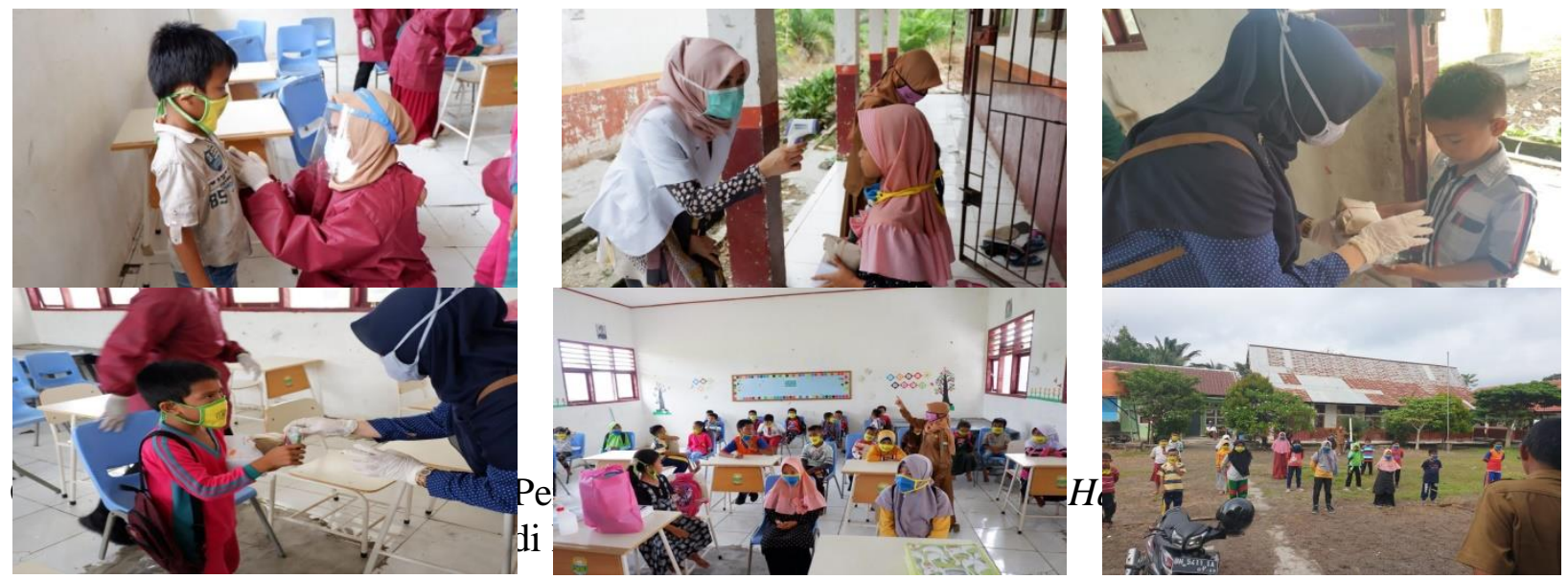

Kegiatan Pemanenan Sayur Setelah Dua Bulan
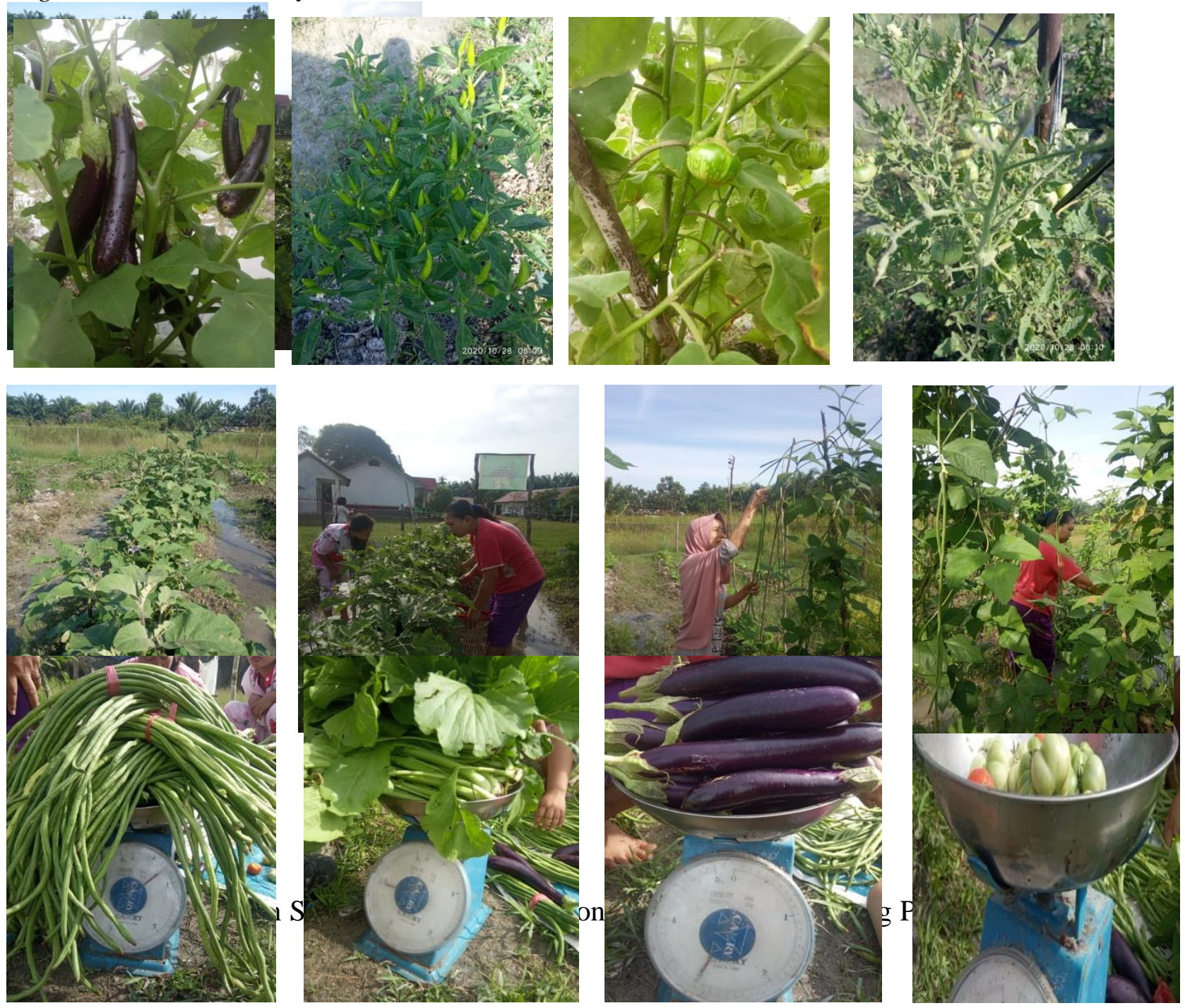

Setelah sekolah dibuka lagi, tim PPM skim Covid Unja kembali menyelesaikan program yang masih tertinggal, yaitu: penyerahan bibit tanaman, makanan sehat, dan vitamin. Pada umur 2 bst, tanaman kacangan panjang, terong, dan tomat sudah bisa dipanen, kemudian ditimbang, setelah itu dibagi ke kepsek, guru, orang tua murid. Kegiatan selanjutnya adalah pembagian 
makanan sehat dan vitamin kepada pihak sekolah (guru dan siswa), serta orang tua murid. Penyerahan bibit tanaman hasil kerjasama antara tim PPM Unja dengan Ikatan Mahasiswa Pendidikan Biologi (IMABIO) Fkip Universitas Jambi kepada pihak sekolah SDN 238/IX desa Sugandi, orang tua murid dan masyarakat. Kegiatan dihadiri oleh pihak sekolah (guru dan siswa), orang tua murid dan anggota BPD desa Nyogan. Foto kegiatan penyerahan bibit, makan sehat dan vitamin

Panen hasil sayuran dari Taman Toga bersama Guru, siswa, dan orang tua murid serta penyerahan bantuan bibit tanaman buah seperti durian, sirsak, jambu biji, dan bibit kayu trembesi.
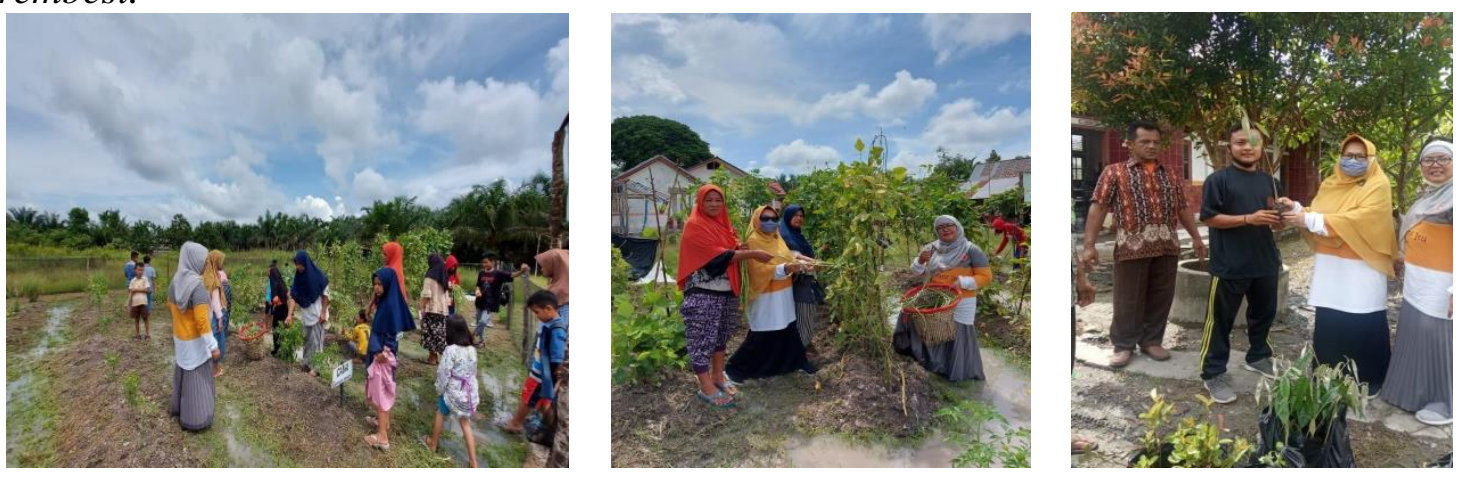

\section{KESIMPULAN DAN SARAN}

Berdasarkan hasil kegiatan pengabdian kepada masyarakat tentang "Pemberdayaan SAD (Suku Anak Dalam) melalui Peningkatan Kualitas Pendidikan Informal dalam Pencegahan Pandemi Covid-19”, di Dusun Sugandi Desa Nyogan telah dilaksanakan dengan 4 topik kegiatan, yaitu: 1). Peningkatan motivasi siswa SDN 238/IX dalam pembelajaran, 2) Peningkatan kualitas pembelajaran siswa SDN 238/IX Sugandi melalui pembelajaran yang menyenangkan, 3) Peningkatan pemahaman siswa dalam menjaga kesehatan mulut, dan gigi, cuci tangan dan jaga jarak dalam mencegah penularan virus covid-19, dan 4) Pengelolaan lahan pekarangan sekolah dengan menanam tanama sayuran, buah dan obat, serta 5) Penyerahan bantuan bibit tanaman durian, sirsak, jambu biji, serta tanaman trembesi.

Kegiatan PPM ini dirasakan manfaatnya oleh masyarakat Dusun Sugandi, untuk itu disarankan kepada pihak Universitas Jambi untuk dapat menjadikan Dusun Sugandi ini menjadi desa Binaan sehingga terlihat kebermanfaatan nya secara siginifikan. Selanjutnya kepada pihak pemerintah Daerah agar dapat menjadi perhatian pada akses jalan yang kalau hujan lebat akan tergenang. Demikian juga dengan lingkungan sekolah agar diperbaiki drainasenya sehingga pekarangan sekolah tidak terendam banjir.

\section{DAFTAR PUSTAKA}

Akbar, S. 2013. Instrumen Perangkat Pembelajaran. Bandung: Remaja Rosdakarya Mulyasa. 2004. Kurikulum Berbasis Kompetensi Konsep, Karakteristik, dan Implementasi. Bandung: Remaja Rosdakarya.

Sani, A.R. 2014. Pembelajaran Saintifik untuk Implementasi Kurikulum 2013. Jakarta: PT Bumi Aksara

Toharudin,U.,\& Setiono.2011. Strategi Belajar Mengajar Biologi. Bandung: Prisma Press. 
Wahyu, A.F.D. 2020. Dampak Covid-19 Terhadap Implementasi Pembelajaran Daring Di Sekolah Dasar Jurnal Ilmu Pendidikan, Volume 2 Nomor 1 April 2020, Halaman 55-61 https://edukatif.org/index.php/edukatif/index

Widiyatyana, W.,Sadia, W.,Suastra, W. 2014. Pengaruh Model Discovery Learning terhadap Pemahaman Konsep IPA dan Sikap Ilmiah Siswa SMP. e-Journal Program Pascasarjana Universitas Pendidikan Ganesha Jurusan Pendidikan Dasar: Volume 4. No 1. Hal 43-48: Diunduh dari http://www pasca.undiksha.ac.id/php Tanggal 7 Januari 2015. 